SECTION 9. Chemistry and chemical technology

Natalia Sergeevna Sorokina

master student,

Tambov state technical University, Russia grnat1991@mail.ru

Andrej Nickolaevich Pakhomov

PHD, associate Professor,

Tambov state technical University, Russia panpost@yandex.ru

Roman Urievich Banin

student,

Tambov state technical University, Russia

Evgenia Urievna Lovyagina

student,

Tambov state technical University, Russia

Elena Anatolievna Chernykh

student,

Tambov state technical University, Russia

\title{
EXPERIMENTAL UNIT FOR STUDYING THE INFLUENCE OF ADDITIVES ON THE PROPERTIES OF CONCRETE
}

\begin{abstract}
Presented the description of the experimental setup and methodology of experiments to study the influence of different additives on the properties of concrete mixtures. The influence of additives of superplasticizers in terms of catching and uniformity of change of volume of the received concrete mix is reviewed.
\end{abstract}

Key words: concrete, additive, superplasticizer, sticks.

\section{УДК 66.047}

\section{ЭКСПЕРИМЕНТАЛЬНАЯ УСТАНОВКА ДЛЯ ИЗУЧЕНИЯ ВЛИЯНИЯ ДОБАВОК НА СВОЙСТВА БЕТОНОВ}

Аннотация: Представлено описание экспериментальной установки и методики проведения экспериментов для изучения влияния различных добавок на свойства бетонных смесей. Рассмотрено влияние добавок суперпластификаторов на сроки схватывания и равномерности изменения объема полученной бетонной смеси.

Ключевые слова: бетон, добавка, суперпластификатор, схватывание.

На сегодняшний день бетон является одним из самых популярных строительных материалов в России. К нему предъявляют очень серьезные требования, так как от его качества и свойств зависит очень многое. Бетон обязан быть долговечным и очень прочным, при этом обеспечивать гидроизоляцию и противостоять механическим воздействиям [1].

Для улучшения качества бетонных смесей в них необходимо добавлять определенные элементы. Нами изучается влияние суперпластификаторов на свойства бетонных смесей [2].

Исследования добавок проводим по традиционно принятой на кафедре «Технологические процессы и аппараты» Тамбовского государственного технического университета схеме [3-5]. 
Для проведения исследований необходимо провести серию замесов с постоянным количеством составляющих бетонной смеси. Первый замес бездобавочный, второй с $25 \%$ раствором суперпластификатора, третий с $30 \%$ раствором, и четвертый с 35\% раствором. Дозировка суперпластфикатора во всех замесах будет составлять $1,8 \%$ по техническому весу.

Основными составляющими бетонной смеси являются цемент, песок, щебень. Нам необходим бетон марки 350, для которого соотвествуют следующие расходы на $1 \mathrm{~m}^{3}:$ цемента=350 кг;песка=750 кг;щебня=1100 кг.

Используем Вольский портландцемент M500 Д0 - это гидравлическое вяжущее вещество, его получают тонким измельчением клинкера и гипса. Клинкер - продукт равномерного обжига до спекания однородной сырьевой смеси, состоящей из известняка и глины определённого состава, обеспечивающего преобладание силикатов кальция (3СaO $\cdot \mathrm{SiO}_{2}$ и $2 \mathrm{CaO} \cdot \mathrm{SiO}_{2} 70-80$ \%) [2].

Основные серии экспериментов проводились нами в бетоносмесителе принудительного действия (рис. 1-2).

Бетоносмеситель лабораторный принудительного действия предназначен для приготовления строительных растворов и бетонных смесей, а также для смешивания сухих смесей в количествах, необходимых для изготовления лабораторных образцов $[6]$.

Форма смесительной емкости и лопастей обеспечивают качественное перемешивание за минимальное время. Плавающие лопасти исключают заклинивание и дробление каменной фракции при перемешивании, обеспечивают работоспособность при значительном (до 10 мм) их износе.

Конструкция обеспечивает хороший доступ к деталям, требующим периодической очистки от налипающих частиц, простоту замены изнашиваемых элементов - лопастей и емкости.
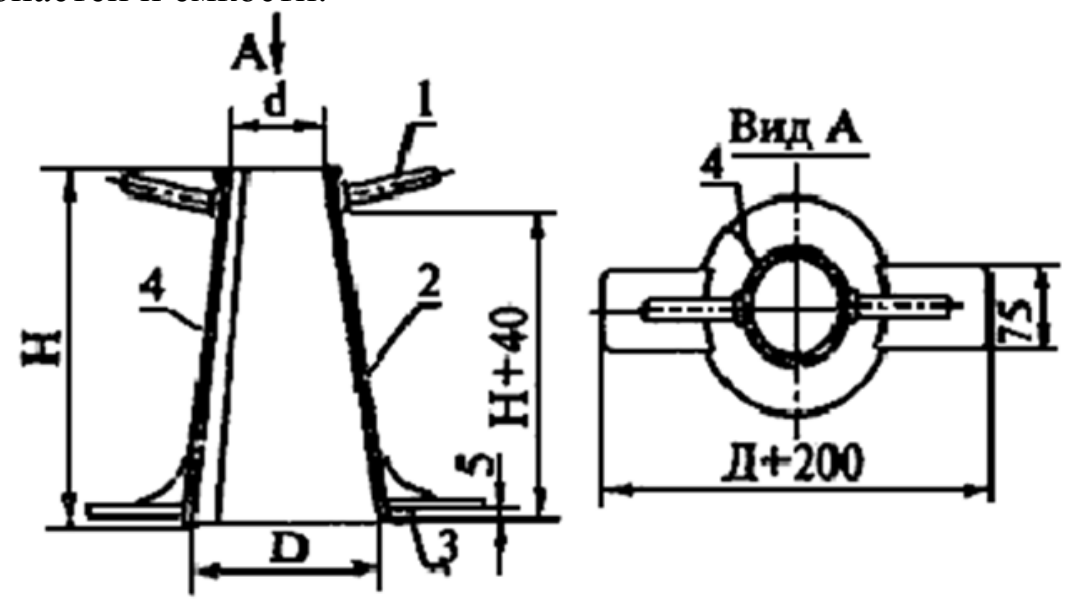

Рисунок 1 - Конус для определения подвижности

1 - ручка; 2 - корпус; 3 - упоры; 4 - сварной шов

Был проведен анализ цемента Вольского М500 Д0 партия 3621 согласно ГОСТ 310.3-76 от 1978-01-01 Цементы. Методы определения нормальной густоты, сроков схватывания и равномерности изменения объема. Нормальная густота цементного теста=24,25; Начало схватывания 3:00 ч., конец схватывания 4:50 ч. 


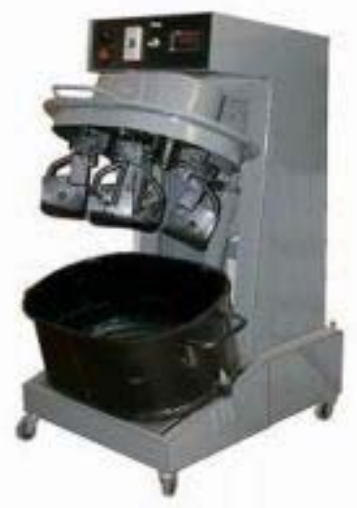

Рисунок 2 - Бетоносмеситель лабораторный СЛ-ЦБ-10 (10 л)

Показано, что крупность песка непосредственно влияет на расход воды в бетоне. Повышенная водопотребность мелких песков отрицательно сказывается на показателях прочности и плотности что приводит к формированию проницаемой структуры. Полученные данные хорошо согласуются с подобными исследованиями проводимыми в России и за рубежом [7-10].

\section{References:}

1. Баженов, Ю.М. Технология бетона / Ю.М. Баженов - М.: АСВ, 2002. - 500с.

2. Дворкин, О.Л. Специальные бетоны. / О.Л. Дворкин - М.: Инфра-Инженерия, 2012. - 368c.

3. Пахомов, А.Н. Возможности самоорганизации дисперсных систем при сушке на подложке / А.Н. Пахомов, Ю.В. Пахомова, Е.А. Ильин // Вестник Тамбовского государственного технического университета. - 2012.- Т. 18, № 3, - С.633 - 637.

4. Пахомова, Ю.В. О возможности прогнозирования качества высушенной послеспиртовой барды / Ю.В. Пахомова, Е.М. Сахарова // Материалы Международной научно-практической конференции, посвященной 75-летию со дня рождения В.Н. Николаева «Теоретические и прикладные аспекты химической науки, товарной экспертизы и образования». - Чебоксары, ООО Издательский дом «ПЕГАС», 25-26 апреля 2013 г. - С. 133 - 133.

5. Пахомова, Ю.В. Экспериментальные исследования свойств жидкой послеспиртовой барды / Ю. В. Пахомова, С.Ю .Слюняева, Т.А. Тришакова, Е.М. Сахарова // Н34 Сборник докладов Международной научно-практической конференции «Наука и образование для устойчивого развития экономики, природы и общества». - Тамбов, Тамбовский государственный технический университет, в 4 т., под научной ред. доктора техн. наук, проф. Н.С. Попова. 2013. - Т.4, - С. 211- 214.

6. Фрей, Х. Справочник строителя. / Х. Фрей. - М.: Техносфера, 2010. - 872c.

7. Christensen R.M. Mechanics of composite materials, New York: Wiley-Interscience publication, 1979, $348 \mathrm{p}$.

8. Molodets A.M. Combustion, Explosion and Shock Waves , 1995, vol. 31, no. 5,pp. 620621. doi: 10.1007/BF00743815.

9. Moraes M.C.B., Elias C.N., Filho J.D., Oliveira, L.G. Materials Research, 2004, vol. 7, no. 4, pp. 643-649.

10. Andreeva A.V. Osnovy fizikokhimii i tekhnologii kompozitov (Fundamentals of physical chemistry and technology of composites), Moscow: IPRZhR, 2001, 192 p. 